\title{
Revitalising African agriculture through innovative business models and organisational arrangements: promising developments in the traditional crops sector
}

\author{
Cosmas Milton Obote Ochieng*
}

\section{A B S T R A C T}

Within the last four years, a number of high profile reports outlining new strategies for pulling African agriculture out of its current impasse have emerged. These include the Comprehensive African Agriculture Development Programme of NEPAD, and the InterAcademy Council Report commissioned by UN Secretary General Koffi Annan. Whilst these strategies are a welcome improvement on those that have characterised African agriculture in the past, it is argued here that like their predecessors, they fail to focus on business-competitive approaches as an integral part of the reform package needed to stimulate African agricultural productivity and development. This paper draws on innovation, business and organisation literature to highlight some of these approaches. It focuses on three concepts: value innovation, lead user focus and organisational value logic.

\section{N T R O D U C T I O N}

Peter Drucker, regarded as the founder of modern management, famously observed that the purpose of a business is to create and keep a customer (Forbes 17.4.2006). Over the last 40 years, African national agricultural research for development systems - research institutes, universities, extension agencies, the private sector, farmer organisations and NGOs,

* Postdoctoral Research Fellow, International Food Policy Research Institute (IFPRI), Addis Ababa, Ethiopia. I thank Judith Heyer, Heike Hoeffler, this editor, and two anonymous referees for their comments on an early draft of this paper. I am grateful to Hanna Wossenyeleh for her excellent research assistance. 
henceforth referred to as African agricultural R\&D systems, or national agricultural research systems (NARS) - have enjoyed the enviable position of not having to create a customer; there were millions of smallholder farmers looking for high-yielding, high-value, disease and drought resistant crop varieties; millions of food-insecure households looking for cheap food supplies; agro-food and chemical companies relying on agricultural raw materials; and a nascent industrial sector which depended to a large extent on the development of the agricultural sector. Agriculture remains the backbone of many African economies, accounting for $57 \%$ of total employment, I7\% of Gross Domestic Product (GDP), and I \% of export earnings on the continent (FAO 2005: I).

Despite this variety of user communities (customers), many African agricultural R\&D systems have been struggling to survive - much like significant sections of their user communities. The United Nations Economic Commission for Africa (UNECA 2005: 9) points out that 'many African indigenous food crops and animals on which $80 \%$ of the African population depends, have reaped few benefits from modern R\&D on their breeding improvements, agronomy, processing and commercialization'. The Commission for Africa (CfA 2005) estimates that nearly half of farmers' harvests in Africa are lost due to poor post-harvest handling, including storage, transport, processing and marketing.

The consequences of agriculture's dismal performance in many African countries have been catastrophic. A continent most of whose people are farmers has been unable to feed itself. Africa is the only region in the world where per capita food grain output has declined over the last four decades (Haggblade et al. 2003; UNECA 2005: 3). Its agriculture is undercapitalised, uncompetitive and underperforming, characterised by relatively low yields and overdependence on primary exports (Haggblade et al. 2003; FAO 2005: 2). Two hundred million Africans (or $28 \%$ of the continent's population) are considered chronically hungry (FAO 2005: I).

Within the last four years, a number of high-profile reports outlining new strategies and directions for African agriculture have emerged. These include: the Comprehensive Africa Agriculture Development Programme (CAADP) of NEPAD (New Partnership for Africa's Development 2002), the InterAcademy Council Report (IAC 2004) commissioned by UN Secretary General Koffi Annan, and the UK Government's Commission for Africa Report (CfA 2005). Whilst these reports are an improvement on the policies that have governed African agriculture in the past, it is argued here that like their predecessors, they fail to focus on business-competitive approaches as an integral part of the reform package needed to stimulate African agriculture out of its current impasse. A recent study on new 
directions for African agriculture (Scoones et al. 2005), for example, rightly observes that social, cultural and political factors are central to any solutions for African agriculture, but neglects to highlight businessorganisational factors.

The CAADP (NEPAD 2002) and the InterAcademy Council report (IAC 2004) are by far the most comprehensive of the recent high-profile reports, and have a lot in common. The IAC report (2004: xviii) 'envisions an African future where increased agricultural productivity, improved food security and an enhanced sustainability of agro-ecosystems can be achieved'. It identifies five underlying strategic themes that should guide agricultural R\&D in Africa towards 20I5: identification of potentially beneficial science and technology options, building impact-oriented research, knowledge and development institutions that address the needs of local farmers, creating and retaining a new generation of scientists to perform future research, and the need for experimentation in creating effective solutions to the problems of African agriculture, 'especially those that empower farmers in Africa to make decisions about their own crops and solutions' (ibid.: xxx).

Through CAADP, African leaders have set themselves the target of reversing the poor record of African agriculture by 2015 through, inter alia: improving the productivity of agriculture to attain an average annual growth rate of $6 \%$, generating dynamic agricultural markets within countries and between regions, integrating farmers into the market economy, making the continent a net exporter of agricultural products, achieving a more equitable distribution of wealth, and being a strategic partner in agricultural science and technology development (NEPAD 2002). Like the IAC, CAADP has identified agricultural research, technology dissemination and adoption as one of four key long-term pillars for Africa's agricultural development (the other three pillars being: extending the area under sustainable land management and reliable water control systems; improving rural infrastructure and trade-related capacities for rural market access; and increasing food supply, reducing hunger and improving responses to food crises). Whilst CAADP's vision is broader than the IAC's, they both suffer from one characteristic flaw: in general they tend to construe the African food security problem more as a supply rather than a demand problem. Consequently, many of their recommendations tend to perpetuate the orientation of African NARS towards addressing supply side constraints to food security, poverty reduction and economic growth, often at the expense of demand side constraints.

This paper argues that this orientation has produced a problematic partial focus on 'users', 'problems' and 'business models' of African 
agriculture. It criticises this orientation by drawing on the business, innovation and organisation literature to illustrate the importance of sophisticated business models and organisational arrangements to African agricultural innovation and development, using modern, if small-scale, business and organisational arrangements in the African traditional crops sector (specifically roots and tuber crops) as case studies. Business/ organisational case studies from this sub-sector are highlighted to show that despite the overall bleak record of African agriculture over the last 40 years, there have been scattered if sometimes short-lived successes, for particular crops, localities and NARS (Gabre-Madhin \& Haggblade 2003; Wiggins 2005). ${ }^{1}$ Behind some of the success stories lies an aspect of organisational or business reform.

THE CASE T T DIES: ROOTS AND TUBERS AND INDIGENOUS

PLANTS S UBSECTORS IN AFRICA

Roots and tubers, notably cassava, sweet potato, yam and potatoes, are among the most important primary crops. They play a critical role in the global food system, particularly in the developing world, where they rank among the top ten food crops (Nweke 2004; Rosegrant et al. 2000: I; Taylor et al. 2004). By 1997, the production of roots and tubers in developing countries had an estimated annual value of more than $\$ \mathrm{US}_{4} \mathrm{I} b n$, or nearly a quarter of the value of the major cereals (Rosegrant et al. 2000: I). These crops have long served as the principal source of food and nutrition for many of the world's poorest and undernourished households. They are valued for their stable yields and production of high quantities of dietary energy under conditions that are often unsuitable for 'less hardy' crops (Alexandratos 1995; Rosegrant et al. 2000: I). As is shown in the rest of this paper, they are increasingly put to multiple uses, notably as food security crops, regular food crops, cash crops, livestock feed and raw materials for industrial purposes.

In sub-Saharan Africa, they are a major source of sustenance, accounting for $20 \%$ of calories consumed (Rosegrant et al. 2000: I). Africa accounts for about $23 \%$ of the world production of root and tuber crops (FAO 2000). In spite of this, African food policy over the last half a century has focused on achieving growth and self-sufficiency in cereals such as wheat, rice and maize (Nweke 2004). The growth of roots and tubers over this period has been driven mainly by area as opposed to yields expansion, partly because until fairly recently little research effort had been directed towards this subsector (Nweke 2004; Rosegrant et al. 2000: 5). 
Historically, the production of roots and tubers in Africa has been restricted to assuring food security. Due to lack of participatory policymaking, virtually all colonial governments neglected their production and trade, in favour of cash crops such as tea, coffee, cotton, and cocoa or cereals (Jones I959; Nweke 2004). The technical (research), marketing and other institutional support that was extended to most cash crops and cereals during this period were not extended to them (Jones i959; Nweke 2004). This led to a relatively prolonged use of non-high-yielding traditional varieties and production techniques in this subsector. Many postcolonial governments continued these policy and institutional biases for much of the first two decades of independence (Nweke 2004; Rosegrant et al. 2000; Taylor et al. 2004). These biases were partly due to the stigma surrounding these crops, as inferior low protein crops whose per capita consumption would decline with increasing per capita incomes. They were also partly due to colonial consumer preferences that prioritised cash crops and cereals over traditional crops, especially roots and tubers (Jones I959).

These biases resulted in national food policies and institutions that biased market signals and institutional incentives in favour of cash crops and cereals. This not only undermined food security in Africa, but also shifted consumer preferences away from traditional commodities which, although long considered staples in vast parts of Africa, managed to undergo 'value-degradation' by acquiring the stigma of 'non glamorous' crops (Jones I959; Nweke 2004). As Rosegrant et al. (2000: 70) have shown, diversification in the utilisation of roots and tubers in developing countries (as food, animal feed, industrial raw materials) has occurred in uneven fashion, beginning in the I96os and I970s in Asia and Latin America, with Africa only taking preliminary steps in this direction from the mid-I99os.

Rosegrant et al. (2000: I) show that the global supply, demand and uses of roots and tubers began to change significantly in the I96os and I970s, fuelled by a trend towards greater diversification in use and greater specialisation in production by crop and region. Between 1983 and 1996 , for example, the consumption of roots and tubers in developing countries increased by $22 \%$ or 45 million metric tonnes (MMT) to reach 253 MMT in I996, with cassava (at 93 MMT) accounting for the largest share of roots and tubers consumed as food, followed by sweet potato $\left(6_{5} \mathrm{MMT}\right)$ and yam (I6 MMT). In a sign indicating the changing trends in utilisation of roots and tubers, sweet potato use as food contracted during this period, whilst its use as animal feed increased rapidly, especially in China. In the I $983-96$ period, the use of sweet potato as animal feed in Asia and Latin America increased by 50\% to stand at 96 MMT (Rosegrant et al. 2000: I). 
Rosegrant et al. (2000) attribute this variation in utilisation of roots and tubers to differences in population and economic growth, cultural factors and urbanisation. They argue that in much of Asia and North Africa, rising incomes, urbanisation and a desire by consumers to diversify away from strictly cereal-based diets, has increased the use of potato as either fresh or processed food, while the same forces have influenced the use of cassava and sweet potato in Asia towards starch, livestock feed and processed foods. In sub-Saharan Africa, they posit that population growth, low and stagnant per capita incomes, and rapid urbanisation continue to generate demand for cassava and other roots and tubers as cheap and starchy staples.

This paper argues that this is only partly true. A combination of smallscale participatory plant breeding, institutional development, value chain analysis and marketing approaches led by innovative organisational partnerships involving multiple stakeholders within African NARS, is increasingly challenging the traditional assumptions, policy and institutional biases that have long characterised traditional crops in Africa. These efforts are leading to the development of new products, food and industrial based, from roots and tubers. These include processed food products (cakes, juices, bread and a variety of snacks), animal feed, industrial and pharmaceutical starch, ethanol and biofuel. Consequently, these crops are increasingly being seen as 'valuable', and are beginning to attract highlevel policy attention and institutional support. The rest of this paper highlights these changes by focusing on the preliminary utilisation of three business concepts in the roots and tubers and indigenous plants subsectors in Africa: value innovation, lead user focus and logic of organisational value. Many African indigenous plants such as Allanblackia, Prunus africanus and rooibos trees have not until recently been put into commercial exploitation, for reasons not unlike those affecting the roots and tubers sub-sector. This paper highlights developments in Allanblackia and Prunus africanus. Rooibos, a tree indigenous to South Africa, is already commercially exploited as a branded tea, with an ever-growing world market.

\section{VALUE IN NOVATION}

Value innovation is defined as the creation of exceptional value for the customer, most effectively when that customer is the most important one in the value chain (Dillon et al. 2005: 3; Sonnack et al. 200I). Technological innovation by itself does not necessarily address customer value; it tends to focus on solutions to given technical problems. For this reason, a new technology (for example, a disease resistant crop variety) may not be 
accepted in the market as having value for the customer. Such a crop variety may not be high yielding, or have acceptable colour, size and other attributes deemed more valuable by farmers and/or customers. This was the case with certain varieties of cassava and sweet potato introduced in east Africa in the I9gos, as a result of the outbreaks of cassava mosaic and brown streak diseases and sweet potato bacterial blight (Mkamilo 2005: I-3; PRAPACE 2003: 28-32). For similar reasons, it has taken the combined efforts of social marketing and farmer field school (FFS) extension approaches to establish producer and consumer markets for the vitamin A enriched orange-fleshed sweet potato in east and southern Africa, where the yellow and white-fleshed sweet potato varieties (which are low in beta carotene or Vitamin A) have been traditionally popular (DfID 2005; SAMRG 2004).

Terziovski et al. (200I: 5) have demonstrated that value innovation intimately links customer value (for example, high yields, suitable colour) to technological innovation (for example, resistance to drought, pests or disease). Value innovation can release a lot of trapped value, and generate fresh growth in markets long assumed to be mature (Accenture 2005; Dillon et al. 2005; Kim \& Mauborgne 200I). Value innovation can take place in product, service and/or delivery processes. This is how Wal-Mart, Starbucks, Dell and Ryan Air for instance, found major new growth opportunities in mass retailing, personal computing and air travel. The power of value innovation to generate new growth in mature markets is not specific to particular industries or sectors.

African agriculture is no exception. Innovative organisational arrangements and business models (typically involving major private sector actors, public research agencies, producers, and different communities of users or sets of customers) is leading to product differentiation or the derivation of high-value products from traditional crops and plants. Innovative business models and organisational arrangements (such as coordinated supply chains) are leading to the increasing employment of indigenous African plants such as Allanblackia and Prunus africanus in modern industrial and medicinal products. Thus, a partnership known as the 'Novella Africa project' between Unilever and African research agencies, farmers and NGOs is developing various relatively high-value household consumer products from the Allanblackia tree in countries across west and east Africa; and in west Africa, Prunus africanus is increasingly being put to modern medicinal uses by European pharmaceutical companies (Attipoe et al. 2006: I80; IUCN 2004; Unilever 2006).

The Allanblackia oil supply chain is perhaps the most advanced of these innovative arrangements. In Ghana, for example, the entire supply chain 
from seed gathering to the production of margarine has been established, leading to improvements in the incomes of farmers, collectors, transporters, small-scale processors and other groups involved in the chain (Attipoe et al. 2006: 185-6). Evidence from other pilot countries (Tanzania and Nigeria) suggests that despite 'teething' problems (with governance capacity issues), the chain is helping to improve local livelihoods and the environment, primarily through the development of new products such as margarine, cooking oil and soap from the Allanblackia tree. During its first year in Tanzania (where at least 3,00o farmers are participating), it generated about $€_{3,300}$ for farmers, rising to $€_{12,500}$ in the second year (Unilever 2006). The UNDP (2005: 5) reports that a baseline survey conducted in eastern Usambara region of Tanzania found that a majority of farmers could earn between I82,000 and 480,00o Tanzania shillings from the crop, annually. This is projected to rise by more than io times by 2015 , when the domesticated plant is expected to start fruiting. The pilot phase of the project has been so successful in Tanzania that the UNDP (2005: 5) reports that: 'Farmer groups are taking initiatives to develop own nurseries with about 7000 seedlings. The Novella project is expanding into other villages.'

The Allanblackia project, like many of the efforts in the traditional crops and plants sub-sectors, emphasises not only technological innovation (developing new products), but also value innovation (better services or ways of delivering these new products to the most valuable customers within the chains). This contrasts sharply with the past orientation of many African NARS, which have overemphasised technological innovation or R\&D (new products rather than better services or ways of delivering these products). However, as Dillon et al. (2005) have argued, when used in isolation, technological innovation is insufficient to create new wealth. For the most successful value innovators, the $R \& D$ contribution is only a portion of the investment, and in some cases, may even be zero. This observation is particularly relevant to African NARS that have a tendency to identify funding as one of their principal constraints (Chema et al. 2003: 9; Gavian et al. 2002).

Akroyd et al. (2004: 365) recently concluded that funding might be the least of African NARS' problems. 'The deterioration in public funding of agricultural research may not be as severe or as universal as is widely perceived. Rates of growth have slowed (although this had leveled off in developing countries by the late ig8os) but real declines are the exception rather than the rule, even in SSA.' In fact, total expenditures for i8 subSaharan African (SSA) countries (excluding Nigeria) rose by $22 \%$ in the I980s, 'faster than the 15 percent in the previous decade ... The relative 
decline in research funding has been most pronounced in SSA, although it is not clear that SSA is particularly underfinanced in absolute terms. It was still spending more in I99I, per researcher or per dollar of AgGDP, than any other developing country region' (ibid.: 363). Of course these figures mask wide variations between countries, but the critical point remains that inadequate funding is insufficient to explain the failures of African agriculture or its R\&D systems. In any case, as shown in the following sections, inadequate physical and financial resources need not be a constraint to value innovation in African agriculture. On the contrary, financial limitations should help inspire value innovation processes.

African agriculture has to find new growth and market opportunities in its traditional and non-traditional markets and products. The continent's competitiveness in its traditional areas of comparative advantage is increasingly being eroded by technological and value innovation in the rest of the world, coupled with increased globalisation which is squeezing its internal and external markets (UNECA 2005: 5). Africa's share of global export trade fell from $5.9 \%$ in Ig8o to under $2 \%$ at the end of the Ig9os, whilst its share of global manufacturing value added declined by half from $0.6 \%$ in 1970 to $0.3 \%$ in the $\operatorname{sggos}(i b i d$.). This paper posits that an orientation to business-competitive approaches may be one way to address this loss of competitiveness.

\section{LEA D USER F O US}

Considerable evidence indicates that users frequently play a significant role in the development of new products (Baker et al. i986; Biemans I99I; Callahan \& Lasry 2004; Kim \& Mauborgne 200 ; Luthje \& Herstatt 2004; Sonnack et al. 200i; Utterback et al. I976). ${ }^{2}$ It has been shown that: (I) many ideas and concepts for new products are developed by users (Voss I985); (2) user needs and requests often directly initiate a significant fraction of innovations within given industries (Biemans I99I; Utterback et al. I976); and (3) a majority of innovations in some industries was initially fully developed by product users (Luthje \& Herstatt 2004; Shaw I985). Shaw (I985) has shown that clinics and doctors have been responsible for $53 \%$ of new product developments in several medical sub-areas, whilst Shah (2000) and Luthje \& Herstatt (2004: 555) demonstrate that it was always the end users who invented the first versions of basic equipment in a variety of entertainment, recreation and food industries: the early versions of protein shampoos go back to housewives' recipes, as do the recipes for baking ready-mixed cakes, the athletes drink 'Gatorade' (developed by the trainer of a college football team), the mountain bike, and basic 
equipment in snowboarding, windsurfing and skateboarding, 'TipEx' (developed by a secretary), 'Linux' and 'Apache' software in the IT industry, to mention but a few.

Research on sources of innovation suggests that in markets with heterogeneous needs, many users remain dissatisfied with the products offered by manufacturers, who may find it unviable to increase product variations to fulfill the needs of all customers. In such situations, users whose needs are not met may expect higher benefits from given innovation opportunities than the manufacturers. This may lead them to take the initiative to develop the products themselves. Sooner or later, such innovations become attractive to other users, although manufacturers are unlikely to recognise the need for them early due to 'weak customer signals' (Luthje \& Herstatt 2004: 558; von Hippel I976). This was the case with the mountain bike (Penning I998) and, as suggested by this paper, is currently the case in Africa with a variety of processed food products that have been developed by partnerships involving public-private-civil society agents and farmer-consumers in the cassava and sweet potato subsectors.

A combination of small-scale participatory plant breeding, institutional development, value chain analysis, and farmer field school approaches, ${ }^{3}$ led by multi-stakeholder partnerships involving international and national agricultural research institutes, national extension systems, aid agencies, farmer-consumers and private sector actors, has pointed to the feasibility of generating a number of high-value processed products from traditional African commodities. In Nigeria, it is estimated that i $6 \%$ of cassava root production was utilised as an industrial raw material (in 200I), I0 \% as chips in animal feeds, $5 \%$ was processed into a syrup concentrate for soft drinks. About I \% was processed into high-quality flour used in biscuits and confectionery, and starch for adhesives and pharmaceuticals (Taylor et al. 2004: 9); $84 \%$ or about 29 million tonnes of production were consumed traditionally as food (ibid.). The feasibility of turning cassava into a 'high-value' crop through new product development led President Olusegun Obasanjo of Nigeria to launch a national presidential initiative on cassava in 2002. This initiative seeks to generate $\$ \mathrm{US}_{5}$ billion annually from cassava production, through inter alia, increased production, processing, value addition and trade (ibid.: $5^{-6}$ ). Following the Nigerian presidential initiative, two high-powered conferences organised by NEPAD in 2003 proposed a Pan Africa Cassava Initiative to promote cassava as a poverty fighter across the continent (ibid.). In Ghana, Bambara groundnut flour has gone commercial after work on it improved its taste, texture and nutritional value (DfID 2005). 
East Africa has also witnessed remarkable new product development in the traditional crops sector. In the Kenyan district of Homa Bay, sweet potato producers have responded to local customers' demand for processed (as opposed to 'fresh') sweet potato by processing sweet potato flour into biscuits and bread. The farmer-processors have grouped themselves into two cooperative bakeries in order to do this. This localised sweet potato chain has enhanced local livelihoods and increased farmer incomes, as they control the entire value chain from production through harvesting and processing to marketing (Appropriate Technology 2004: 49). The machinery used by the bakeries has been developed through collaboration between local artisans and scientists at the Kenya Industrial Research Institute (KIRDI). In other districts across the country, 'Nutribusiness Development Project', which seeks to train and organise women groups into nutrition, food processing and product commercialisation cooperatives, has succeeded in developing two nutri-porridge products ('Tupcho', 'BASCOT') which are a mix of products based on local produce with enhanced nutritional value (USAID 2006). The nutribusiness project is a partnership between the universities of Nairobi, Tuskegee and Pennsylvania, Kenya Agricultural Research Institute (KARI), farmer and community-based organisations. Small-scale processing of sweet potato into a variety of human and livestock food products is also under way in Uganda (DfID 2005: i).

The important thing about these case studies is that unlike traditional commodity research within African NARS, the research and development processes in these cases are more interactive and less linear in nature. They involve collaboration between a variety of stakeholders - producers, researchers, public-private and civil society actors - and a variety of usercommunities. This is a significant re-orientation, which could reduce innovation costs of African agricultural R\&D systems. Research has shown that due to sticky information about user needs (where stickiness of a given unit of information is defined as the incremental expenditure required to transfer a unit of information from its point of origin to another party), user innovation costs can be significantly lower than manufacturer's (Luthje \& Herstatt 2004: 559; Von Hippel I998). 'User needs often enough are sticky because they are deeply rooted in the personal experience of individuals and can hardly be encoded in explicit terms (tacit knowledge)' (Luthje \& Herstatt 2004: 559). This is especially so in the food industry, often characterised by 'flavours', 'recipes' and 'tastes'. Involving user communities early in the research and development process, as was piloted in these case studies (through farmer field schools), can reduce the costs of innovation or development of new products. 
The farmer field school (FFS) approach has evolved from its early focus on participatory plant breeding approaches to include participatory marketing approaches, value chain analysis and enterprise development (Davis 2006; Holland \& Blackburn I998; Mayoux 2003; Sperling et al. 200I; Tripp et al. 2005; Vernooy 2003). Interactive learning can be said to be its overriding principle. Thus, it essentially views innovation as an interactive process, shaped by a combination of institutional arrangements, social conventions, prevailing scientific infrastructure and interrelationships between firms (or the private sector), producers and user communities. In two significant ways, it is a critique of the linear model of innovation that long characterised African NARS.

In general, the linear model of innovation had two fundamental flaws. First, "its absence of feedback loops meant that "upstream" activities like R\&D for example, would have little or no opportunity for learning about their effects on user communities' (Morgan 1997: 493). Secondly, it suffered from an elitist conception of knowledge, which extolled 'scientific knowledge' at the expense of 'lower' forms of knowledge, including most notably, tacit knowledge (ibid.; Rosenberg 1976). Interactive learning, as embedded in FFS for example, seeks to provide avenues for both feedback loops and 'lower' level knowledge, not only between researchers and producers but also between users, producers, processors and suppliers. Although the FFS is not without its flaws (relatively high investment costs, expensive to sustain and to replicate, tends to exclude relatively poorer farmers (Davis 2006)), in its most advanced form, as employed in some parts of Africa (for example in sweet potato value chains), it embodies, albeit in relatively crude forms, elements of the principles of 'collaborative manufacturing' to which the success of many modern Japanese firms has been attributed (Nishiguchi I994).

Nishiguchi (1994) argues that Japanese firms benefited from integrated supply chain systems that ensured mutual benefits for both suppliers and purchasers (customers) from the synergistic effects of collaborative problem solving, and corresponding improvements in product design, quality, delivery and prices. 'Through a whole series of institutional innovations -like the resident engineers based in the customer's plant, who were thus well placed to feed back information on the use of their products; supplier associations which disseminated "best practice" among their members; and jointly agreed conventions to share the profits of interfirm collaboration - the leading Japanese firms were able to reap the benefits of an awesomely effective system of interactive learning' (Morgan I997: 494). 
The benefits of elementary forms of 'interactive learning' and 'collaborative manufacturing' in the African traditional crops sector can be discerned in increasing value innovation (in this case development of new products) in some traditional commodity chains. As Taylor et al. (2004: 9) demonstrate, in Nigeria, cassava is beginning to challenge its stigma as a less glamorous crop and is increasingly gaining an urban market presence as a result of its increased utilisation as processed food. 'Cassava appears to be a food of choice even in the face of alternative food options in urban areas' (ibid.).

The literature on product innovation suggests that not all users are active innovators. Innovation by users is often concentrated in progressive segments of user communities known as 'lead users' (Kim \& Mauborgne 200I; von Hippel I986). These users have two distinctive characteristics: they face new market needs significantly earlier than the majority of users in that market, and they are positioned to profit strongly from innovations that provide solutions to these needs (Luthje \& Herstatt 2004: 556). Lead users, as shown in Figure I, have needs that are well ahead of the market trend. Over time, however, more and more people feel the same need. Targeting them is thus critical, as lead user innovations can generate competitive advantage. Ironically, Kim \& Mauborgne (2001: I3) observe that in most industries competitors converge around a common definition of who the target customer is, when in fact there is a chain of customers or user communities who are directly or indirectly involved in the buying decision: purchasers (for example, corporate purchasing agents who are not the actual users), ordinary users, lead users and influencers (for example, doctors in the pharmaceuticals industry).

In many African agricultural R\&D systems, the 'herd instinct' has generally converged on the so-called 'end user' - one kind of user community, encompassing subsistence farmers and consumers (for food crops), and raw materials processing industries (for cash crops). There are good reasons for this. Many African NARS were designed to target this community of users: ordinary smallholder farmers, fresh food consumers, and raw material-dependent processors. The original structural features of African NARS were established by colonial governments, and tended to be narrowly focused, often concentrating on the production of export crops, in raw form, for use as raw materials by European industries (Lynam \& Elliot 2004: I45). With independence, these systems were adjusted to include the integration of African smallholders into commercial agriculture, and to address the needs of subsistence farmers and the rapidly expanding food needs of these countries. There has since been 


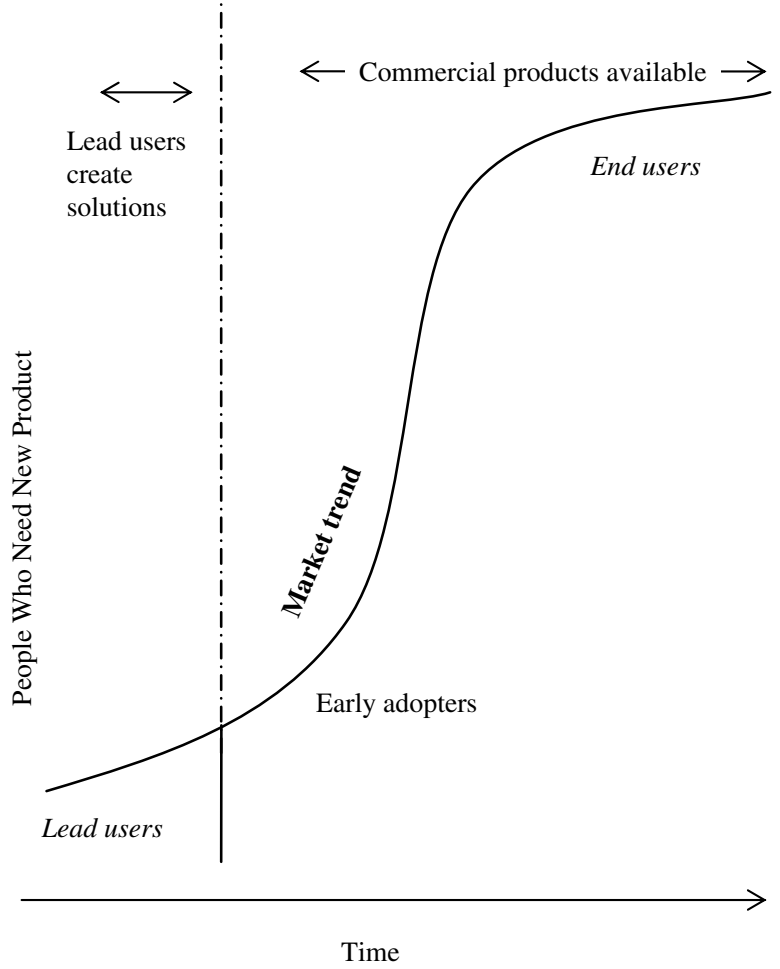

FIGURE I

The lead user curve. Note: The curve illustrates the shape of a market trend. Lead users have needs that are well ahead of the trend; over time, more and more people feel the same need. Source: Adapted from Sonnack et al. 2001 : $3^{8}$

little challenge to this dual set of user-communities in many African R\&D systems (Lynam et al. 2004).

This is perhaps best exemplified by the Kenyan NARS. Kenya has the third largest national agricultural research system in sub-Saharan Africa, after Nigeria and South Africa (Lynam et al. 2004). Until the early ig8os, its agricultural sector was much celebrated as exceptionally successful in sub-Saharan Africa (Bates I989; Lofchie 1989). Post-colonial Kenya's early agricultural successes are often traced to the Swynnerton Plan of I954 (Bates I989; Ochieng 2005). Named after its lead author (then Assistant Director of Agriculture, Roger Swynnerton), the Plan laid the foundation of the national agricultural innovation system in postcolonial Kenya. ${ }^{4}$ It set in place institutional, organisational, technological, and managerial and policy innovations that have dominated post-colonial Kenyan agriculture: private property rights to land, contract farming, 
public-private partnerships, politico-economic agrarian organisations and management. Ochieng (2005) has argued that whilst these innovations were successful in integrating smallholders into commercial agriculture as primary commodity producers, they were not geared towards agricultural value-addition or value innovation. To illustrate, despite the fact that Kenya has the third largest NARS in sub-Saharan Africa, its agricultural value added is no better than in many African countries with relatively smaller systems (World Bank 2002). It is not that the Swynnerton Plan did not create a successful agricultural innovation system - on the contrary, the plan succeeded in achieving exactly the kind of agricultural innovation system it was designed to achieve (Thurston I987) - but rather that the post-colonial Kenyan state lacked the strategic foresight to build on the innovative successes of the plan, by shifting from integrating smallholders into commercial agriculture as producers of primary commodities, into a much more value-added, value innovation driven agro-industrial transformation. In the absence of this strategic foresight and reorientation, the technological, institutional, organisational and policy innovations of the agricultural innovation system created by the Plan became a constraint, limiting further development of Kenyan agriculture, beyond its narrow specialisation in primary commodity production for one set of user communities - end users.

Many African NARS grew out of strategies similar to the Swynnerton Plan. Like the Kenyan NARS, they are characterised by relatively little value innovation and a predominant focus on end users. Given the acute poverty and foreign exchange constraints that many African countries faced at independence, it is understandable that the R\&D efforts of (public) agricultural research institutes should have been directed towards addressing food security and foreign exchange needs. It can also be reasonably argued that in situations of extreme resource poverty, there can be any number of constraints to addressing the needs or demands of given user communities, regardless of the potential benefits that may accrue from targeting them. In such situations, the mere identification of the existence of multiple user communities, including lead users, may not mean that it is cost-effective to target and engage in 'collaborative manufacturing' with them. The costs of targeting some user communities may also be prohibitive for resource constrained R\&D firms.

This implies caution against the simple translation of business models developed for modern corporations in the industrial world into developing country agriculture. Nevertheless, as argued in the next section, African R\&D systems can learn a lot from some of these models and arrangements, including how to address the question of resource constraints, by 
making the most use of their available resources. Similarly, as the successes of interactive learning embodied in FFS approaches in Africa have shown, some organisational arrangements and business models are not so culturally embedded as to be inapplicable elsewhere. Previous claims that the Japanese model of collaborative manufacturing was culturally embedded, for example, have recently been dismissed (Morgan 1997: 494).

One lesson that African agricultural R\&D systems can learn from the lead user concept is that challenging an industry's conventional wisdom about which buyer group to target can lead to the discovery of new market space (Kim \& Mauborgne 200I). New product development (NPD) is often associated with high risks. Aligning key activities within NPD projects with the needs of actual and potential customers can reduce the risk of failure. 'A customer focus in this sense seems to foster product advantage in terms of quality, reliability and uniqueness which in turn is positively correlated with product market performance' (Luthje \& Herstatt 2004: 553). It is for this reason that leading companies such as Johnson \& Johnson are increasingly working with lead users. The lead user process is a multistage method for developing breakthrough products (Sonnack et al. 200I). 'It is based on the fact that many commercially important products are initially thought of and even " prototyped' by lead users - companies, organizations or individuals that are well ahead of market trends. Their needs are so far beyond those of the average user that lead users create innovations on their own that may later contribute to commercially attractive breakthroughs' (Sonnack et al. 200r: 32). The lead user method is thus one instrument for creating value innovation.

A second lesson that African agricultural R\&D systems can learn from the lead user concept is that there are different kinds of users or user communities. Different sets of users or user communities may latch on to different innovation processes. Thus, the emphasis on meeting the needs of food-insecure households through improved crop varieties and production techniques, whilst defensible and morally and politically urgent, may be only one way to address the problem. As Sen (I981, I985, I999) and others (Watts 1983, 2000; Watts et al. 1993) have argued, whilst food security is an entitlement, it is much more than food availability or having sufficient food to meet national needs. It is also about access to and distribution of food. Food insecurity (or famine) can be construed as both a demand and supply problem. Weak scientific and technological capacities are insufficient to explain food insecurity (or famines), and addressing this, whilst important, cannot be the only basis of a nation's response to food insecurity, poverty, famines or the pursuit of capabilities and entitlements (see Sen r981, r985, I999). 
There are political economy reasons for why people starve, are food insecure, poor, or lack capabilities and entitlements. As Sen (I98I) has noted, India has not suffered a major famine since its independence in I947, because of: (I) its emphasis on addressing demand side constraints (through work programmes and food distribution for instance); and (2) its active democracy and free press has held its leadership to account (through voting and competitive elections). Of course, the emphasis on demand side constraints was matched by an equal emphasis on supply side constraints, most notably through the Green Revolution (FAO 2005: I).

Capabilities and entitlements are embedded within socio-political processes, and according to Watts (2000: 62) are constituted and reproduced through conflict, negotiation and struggle. If food insecurity, poverty, and famines are a result of 'capability and entitlements failure', the overriding objective must be to overcome vulnerabilities or demand and supply side constraints to food. This calls for a much more complex and wide-ranging response than highlighted in recent high-profile reports on future directions of African agriculture. This paper suggests that, at least in part, this calls for a more sophisticated consideration of differentiated communities of both producers and users, which could facilitate the recognition within African NARS that there are multiple sources of, and responses to, innovation, which can be harnessed for poverty reduction and development.

As these case studies have shown, a lead user focus need not exclude smallholders, or undermine efforts aimed at securing food security. Thailand and China, for example, have made greater strides in improving the livelihoods of their cassava and sweet potato producers by targeting different user communities for these products, processing cassava and sweet potato into animal feed, fuelled by (and fuelling) the surging demand for meat, milk and other livestock products (Rosegrant et al. 2000). The innovative capability of significant segments of African smallholders has been amply demonstrated (Brokensha \& Warren I980; Kuyek 2002; Reij \& Waters-Bayer 200I), and is not questioned here. What the elementary forms of lead user focus from these case studies imply is that part of the challenge facing African agricultural R\&D systems is how to identify and target different user communities, including lead and end users, so as to facilitate innovations and the competitiveness of African agriculture. By looking across buyer groups and identifying their user communities, African agricultural R\&D systems can gain new insights into how to redesign their 'value curves' (Kim \& Mauborgne 200г: 8-9), to focus on previously overlooked sets of customers. This may lead to the creation of new market space for African 'traditional' commodities, and open up markets for new 
African agricultural products. Many of the case studies highlighted here show that the near exclusive focus by many African R\&D systems on only one set of user communities has constrained product differentiation/ diversification, value innovation, market creation, and the competitiveness of African agriculture. This may have been due partly to resource constraints. The next section highlights ways through which some of these constraints can be mitigated.

THE L O G C O ORGANISATIONAL VALUE

Agricultural innovation is a complex process whose possible outcomes are typically uncertain. It requires the reduction of technological, commercial, organisational and social uncertainties. It must be demonstrably feasible (I) technologically; (2) commercially; (3) organizationally; and (4) socially (Martin \& Hall 2005: 274). Teece (I986) has argued that even if a new product or process is technologically viable, there is no guarantee that the innovator will appropriate the benefits of the innovation - the development and exploitation of technology should thus be congruent with the overall strategy and capabilities of the firm. Socially (agricultural) innovation must recognise and accommodate potentially detrimental side-effects on society (Popper I959).

Technological innovation has the potential to generate new, often difficult to imitate, organisational capabilities and competencies, which can either lead to competitive advantage or disrupt competency along the innovation value added chain (Christensen I997; Martin \& Hall 2005: I; Penrose I959; Tushman \& Anderson I986). Part of the challenge facing African NARS is how to organise and manage for profitable innovation in an increasingly competitive world. This calls for an organisational value logic - an organisation's business model or the way an organisation creates value (Accenture 2005) - that many African R\&D systems have not yet mastered.

As noted, African agricultural R\&D systems have been organised in ways that are antithetical to value innovation and lead user focus. For the most part, these systems have operated with little if any systemic intraorganisational let alone inter-organisational interaction or linkage (Chema et al. 2003; Lynam \& Elliot 2004). The IAC (2004) argues that many African NARS require organisational structures that facilitate linkages and interactions between complementary institutions, and reward structures that encourage managers, scientists and academics to communicate and cooperate with each other. Increasingly, donors are pushing for such systemic interactions and linkages, through for example competitive 
grants systems that prioritise collaboration between organisations (Chema et al. 2003).

The weak or non-existent linkages within African NARS represent a failure to exploit synergies despite acknowledged human, physical and financial constraints (IAC 2004: I44). Many African NARS are still at what Rothwell (I994) has called the first generation innovation stage (technology push). This was the foundation of the industrial revolution innovation came with new, technologically advanced products and means of production, both of which were pushed onto the market (Terziovski et al. 2001: 2). This approach to innovation is largely supply driven. In African agricultural R\&D systems, it has seen scientists developing plant varieties and production techniques which are then pushed onto farmers as end users. The increasing donor push towards demand driven approaches is essentially aimed at pushing these systems towards second generation innovation or the demand pull stage. Here the focus is on customer or market determined needs. Thus, nearly every African national agricultural research institute (NARI) now has a market orientation approach, typically manifested in the creation of departments of socio-economics and post-harvest activities.

Whilst African NARS have been grappling with mastering second generation innovation, much of the world has gone through third, fourth and fifth generation innovations (see Rothwell I994). Third generation innovation involved coupling the first and the second generation innovations (push and pull). 'The market might need new ideas but production technology refined them. Alternatively, R\&D developed new ideas that marketing refined with market feedback. R\&D and marketing were linked' (Terziovski et al. 200I: 2). The fourth generation was an integrated model which saw the tight coupling of marketing and R\&D activity, together with strong supplier linkages, and close coupling with leading customers. Fifth generation innovation involves systems integration and networking models, and builds on the fourth generation model by including strategic partnerships with suppliers and customers, using expert systems and employing collaborative marketing and research arrangements (ibid.).

This is where the logic of organisational value in African agricultural R\&D systems comes in. Value creation comes from a firm's ability to continuously reconfigure its resources to address problems that are qualitatively and significantly new. In the developed world, many enterprises increasingly operate in situations in which traditional assets, (physical and monetary) are of shrinking importance to business success. These are being replaced in significance by assets such as customer relationships, intellectual property, and innovative organisational and management 
arrangements (Accenture 2005: 4). Whilst many enterprises in African agriculture are not in a situation where physical and monetary resources are of decreasing importance, the fact that they still face these constraints suggests that they could benefit by tapping into the 'new' types of assets enumerated above. One way of doing this is by developing combinative capabilities, or the capacity to leverage internal and external knowledge assets.

\section{Leveraging knowledge assets and combinative capabilities}

In the 'Core Competence of the Corporation', Hamel \& Prahalad (I990: 79-9I) attribute the rise of many relatively resource-poor Japanese firms in the ig8os (especially in electronics, semiconductor and office equipment industries - Honda, NEC, Canon) against their resource-rich US and European competitors to the fact that they were able to turn resource disadvantage into competitive advantage by leveraging resources and capabilities (creative and efficient use of their internal and external competencies). They did so notably through combinative capability or resource combination. Resource recombination is the process either of combining existing products into new products, or of synthesising technologies into a new technology with a new functionality, whilst combinative capability is a firm's ability to make efficient use of its resources by combining either internal resources or internal and external resources, to create new resource combinations that are valuable, non-substitutable and hardly imitable (Koruna 2004: 508).

The idea of resource recombination as a source of innovation is not new. Schumpeter (1934), Gilfillan (I935), Usher (1954) and Penrose (1959) had long suggested that a firm's ability to creatively recombine its resources ('creative destruction') can be a major source of competitive advantage. Developing this capability, and organising and managing firms so that the process is not left to chance, is the hard part. Koruna (2004: $5^{\text {II }) ~ h a s ~ i d e n t i f i e d ~ m a n y ~ o r g a n i s a t i o n a l, ~ c o g n i t i v e ~ a n d ~ c u l t u r a l ~ b a r r i e r s ~ t o ~}$ combinative capability, all of which typically characterise African NARS. These include intra-organisational boundaries, disciplinary orientation or engineer syndrome (lack of interdisciplinary or transdisciplianry collaboration), tacitness and dispersion of knowledge, identifying economic value of recombined resources, and bounded rationality (identifying valuable combinations of knowledge is dependent upon agent cognitive capabilities). The IAC (2004: I 8) noted that in 54 African countries, the Ministry of Agriculture was primarily responsible for agricultural research in 44 countries, whilst the Ministry of Science was responsible in Io 
countries. Within these ministries, there were separate departments responsible for individual components of the NARS, making coordination difficult.

Combinative capability or the leveraging of knowledge assets can occur in a variety of forms with varying degrees of complexity. Simpler, not mutually exclusive mechanisms include: (I) multiple applications of technology or knowledge; (2) external acquisition of technologies; (3) external commercialisation; and (4) platforms (Koruna 2004). Multiple application of knowledge or technology involves leveraging resources by identifying further deployment for an application of already existing products. In the African context, this would include the recent application of traditional commodities in a number of industrial and food products. Often, customers rather than firms discover alternative uses of products (Koruna 2004: 505). This requires a good blending of technological and market knowledge or a lead user focus.

No single firm can keep pace with the development of all relevant technologies. African R\&D systems need not generate all the technologies they need. Many technology-based firms have learnt the art of acquiring external technologies cost effectively through either institutional or noninstitutional means (Koruna 2004: 506). The former (institutional) includes contract R\&D, licensing, technology buying, joint-ventures, strategic alliances and virtual corporations (Barabaschi i992; von Hippel I987). The latter includes informal know-how trading (von Hippel i987), reverse engineering, and recruiting personnel from other companies or competitors (Koruna 2004: 506).

African R\&D systems have had little engagement with many of these processes. Of the former (institutional), only cooperative $R \& D$ and licensing have been tried on any scale. Cooperative R\&D includes attempts by national agricultural research institutes (NARIs), the CGIAR (Consultative Group on International Agricultural Research), civil society and private sector actors to establish coordinated supply chains in certain commodities. The 'African Novella Project' (a coordinated supply chain in Allanblackia oil) is a good example of this (Attipoe et al. 2006). In terms of non-institutional technology access, only personnel recruitment (facilitated by foreign aid or technical assistance) has been employed on a significant scale, although this has often occurred against the backdrop of brain drain from the African NARS (IAC 2004: I80-I).

Firms can also leverage resources through external commercialisation. As Koruna (2004: 507) has argued, 'the more firms are relying on the external acquisition of technological knowledge, the larger the opportunities for firms in possession of state of the art technological knowledge to 
exploit such opportunities'. This is an underexploited area in many African agricultural R\&D systems, although the shift towards demand pull research may provide an opening for such undertakings. That would require some innovative organisational arrangements that reconcile the 'public goods nature' of the research conducted by many African R\&D systems which are largely public agencies, with the need to leverage resources for their increased competencies and competitiveness.

Platforms are a set of sub-systems and interfaces that form a common structure from which a stream of related products can be efficiently developed and produced (McGrath i995). Within the platform concept, products and technologies on which these products are based are no longer being treated as separate units (Koruna 2004: 507). It exploits the economies of scale and scope, but is a more advanced form of leveraging resources. Many African NARS may not be in a position to relate to the concept in the short term.

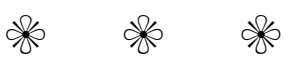

This paper has highlighted the limitations of business and organisational models that have governed African agriculture and its R\&D systems over the last 40 years. It has shown that the lack or neglect of businesscompetitive approaches has undermined value creation, at least in the traditional crops sector, to the detriment of the competitiveness of African agriculture. It has also shown that innovative organisational arrangements and business models can help create new market space and value addition for African agricultural products, for example by responding to the needs of a variety of user communities.

It must be emphasised that many of the 'successes' highlighted here are scattered and isolated pilot schemes established mainly through 'donor driven trends', notably including participatory and pluralistic research and extension approaches, and competitive grants systems that have encouraged a number of public-private-civil society partnerships. The challenge of institutionalising these approaches, wholly or in part, and up-scaling and out-scaling the scattered successes remains. This paper does not claim to have the solution to this challenge. But one lesson that can be derived from the case studies presented here is the need for a paradigmatic shift in the way agricultural $R \& D$ systems in Africas are conceived, and the way they themselves conceive of their customers or user communities.

Agricultural innovation is multifaceted. It can be technological, institutional, organisational or policy-based. In Africa, for reasons ranging 
from international and national power relationships to internal political expediency, it is often conveniently conceived largely in technological terms (Mackenzie I998). It can be argued that a national agricultural innovation system is embedded in historical, biophysical, socio-economic, politico-institutional, business-organisational structures and relationships (global and national) that obtain in particular societies (Duncan I996). As Mackenzie (I998) and Ochieng (2005) have shown, throughout the twentieth century, colonial and post-colonial governments in Africa used combinations of socio-economic and political policies and institutions such as land laws and market restrictions, price regulations, legal and institutional frameworks, political space for contestation of policy and urban/ agribusiness/ethnic-biased policies to prey on smallholder agriculture, with devastating consequences for sustainable agriculture in Africa.

Contrary to the assertions of technologically biased conceptions of agricultural innovation, many of the problems afflicting agricultural productivity and development in Africa derive from the broader historical, economic, social-political and business-organisational environment. Theodore Schultz (I979) was right when he argued that differences in productivity of soils are not useful in explaining why people are poor in long-settled parts of the world. This paper has argued that businessorganisational issues in African agriculture merit urgent and high-level attention.

Recent findings in India contending that the poor constitute a viable market for the private sector (Prahalad 2005) support a vast literature on the informal economy in developing countries which emphasises key characteristics of the poor as rational, efficient, entrepreneurial, technologically adaptive, brand and value conscious (de Soto 2000; Hart I973; ILO ı972; Moser I978; Portes et al. I989; Schultz i964). One important implication for Africa is the need for the private sector to re-think its customer logic by viewing the poor, who constitute a majority of the African population, as potentially their most important customers. Such a revaluation of business logic may facilitate private sector 'buy in', not only in institutionalising business-competitive approaches, but also in up-scaling and out-scaling scattered successes in African agriculture.

Projected changes in demographics, urbanisation and consumer preferences suggest the existence of incentives for enhanced private sector engagement with the 'poor user community' in Africa. Some studies project that future growth in African agriculture lies in intra-African trade in traditional commodities such as roots and tubers (Minae 2005). Minae (2005) estimates that by 2030, 440 million people will be living in African 


\section{cities, creating an African urban market growth I4 times greater than export market growth. These new urban dwellers are likely to still rely on the rural areas for their food needs - especially for staples such as roots and tubers.}

\section{NOTES}

I. Where 'success' is defined as a measurable improvement in net welfare (including but not limited to income growth, improved nutrition, greater sense of well-being), with broad-based impact and achieved in an environmentally sustainable way (Gabre-Madhin \& Haggblade 2003: 7).

2. Although a prominent minority argues that customer-orientation approaches may be detrimental to innovation (Hamel \& Prahalad I994; Martin I995).

3. Farmer field school is at its most advanced form, an interactive research-extension-marketingenterprise development approach between researchers, farmers, private, public, private and civil society actors and consumers (Davis 2006; Tripp et al. 2005).

4. The Swynnerton Plan was a response to the Mau Mau war of independence, and had twin political and economic objectives: to ensure political stability in the colony by creating a class of yeomen African farmers whose prosperity would not only lead to allegiance and support for the status quo, but would also absorb potentially rebellious or radical landless Africans as wage labourers. It went beyond the simple legalisation of African production of high-value cash crops to seek two fundamental objectives: (a) the promotion of African commodity production through the provision of administrative and technological services such as agricultural research programmes, marketing boards and crop authorities to facilitate the uptake of new crops, and credit schemes, for which private land would serve as collateral to enable cash-strapped farmers to produce high-value export crops; and (b) the establishment of private property rights to land which were viewed as a means of internalising the benefits of innovative activities, providing economic incentives for productivity increases in agriculture, and solving what was regarded as chronic and costly litigation arising out of the customary land tenure system. In effect, the plan sought to establish both market and state support for the commercialisation of African agriculture (Ochieng 2005).

\section{R E F E R E N C E S}

Accenture. 2005. 'Chains, shops, and networks: the logic of organizational value', Research Report, Accenture, Institute for High Performance Business.

Akroyd, S., R. M. Kiome \& C. G. Ndiritu. 2004. 'Financing agricultural research', in J. Lynam, C. G. Ndiritu \& A. Mbabu, Transformation of Agricultural Research Systems in Africa: lessons from Kenya. East Lansing, MI: Michigan State University Press, 415-23.

Alexandratos, N. I995. World Agriculture: towards 20I0. New York: Food and Agriculture Organisation of the United Nations and John Wiley and Sons.

Anderson, B. A. I979. 'Acquiring and selling technology: marketing techniques', Research Management 22, $2: 26-8$.

Appropriate Technology. 2004. 'The sweetest potatoes of all', Appropriate Technology 3I, 4: 49.

Attipoe, L., A. van Andel \& S. Nymae. 2006. 'The Novella Project', in Slingerland, M., R. Ruben \& H. Nijhoff, eds. Agro-food Chains and Networks for Development. Amsterdam: Springer.

Baker, N. R., S. G. Green \& A. S. Bean. I986. 'Why R\&D projects succeed or fail', Research and Management, 29, 6: 29-34.

Barabaschi, S. I992. 'Managing the growth of technical information', in N. Rosenberg, R. Landau \& D. C. Mowery, eds. Technology and the Wealth of Nations. Stanford, CA: Stanford University Press.

Bates, R. I989. Beyond the Miracle of the Market: the political economy of agrarian development in Kenya. Cambridge University Press.

Biemans, W. G. I99I. 'User and third-party involvement in developing medical equipment innovations', Technovation II, 2: 163-82.

Brokensha, D., \& M. Warren. 1980. Indigenous Knowledge Systems and Development. Lanham, MD: University Press of America. 
Callahan, J. \& E. Lasry. 2004. 'The importance of customer input in the development of very new products', R\&D Management 34, 2: 107-20.

Chema, S., E. Gilbert \& J. Roseboom. 2003. 'A review of key issues and recent experiences in reforming agricultural research in Africa', Research Report 24. The Hague: ISNAR.

Christensen, C. M. 1997. The Innovator's Dilemma. Boston, MA: Harvard Business School Press.

Clark, N. 2005. 'Science policy and agricultural research in Africa', paper prepared for NEPAD.

Commission for Africa (CfA). 2005. Our Common Interest. London: Penguin.

Davis, K. 2006. 'Farmer field schools: a boon or bust for extension in Africa?' Fournal of International Agricultural and Extension Education I3, I: 9I-7.

de Soto, H. 200o. The Mystery of Capital: why capitalism triumphs in the west and fails everywerere else. New York: Basic Books.

Department for International Development (DFID), Crop Post Harvest Programme. 2004. Annual Report. London: DfID.

Dillon, T. A., R. K. Lee \& D. Matheson. 2005. 'Value innovation: passport to wealth creation', available at: www.smartorg.com/downloads/ValueInnovation.IRI.Maro5.pdf. accessed I6.09.2005.

Duncan, C. 1996. The Centrality of Agriculture: between humankind and the rest of nature. Montreal: McGill-Queen's University Press.

FAO. 2000. FAOSTAT. Rome: FAO.

FAO. 2005. 'Special event on green revolution in Africa', background document prepared by SDR, Committee on World Food Security, 3ist session, 23-26 May.

Forbes, New York; 17.4.2006.

Gabre-Madhin E. \& Haggblade S. 2003. 'Successes in African agriculture: results of an expert survey', Discussion Paper No. 53, Markets \& Structural Studies Division, IFPRI, Washington, DC.

Gavian, S., D. W. Brinkerhoff \& J. D. Gage. 2002. 'Sustainable agricultural research systems: findings and lessons from reforms in Côte d'Ivoire, Ghana, Senegal, Tanzania and Uganda', Bethesda, MD: Abt Associates.

Gilfillan, S. 1935. Inventing the Ship. Chicago, IL: Follet.

Haggblade, S., P. Hazell, I. Kirsten \& I. Mkandawire. 2003. 'African agriculture: past performance, future imperatives', paper presented at the InWEnt, IFPRI, NEPAD, CTA Conference, Pretoria, I-3 December.

Hamel, G. \& G. K. Prahalad. I990. 'The core competence of the corporation', Harvard Business Review 68, 3: 79-9I.

Hamel, G. \& C. K. Prahalad. 1994. Competing for the Future. Boston, MA: Harvard Business School Press.

Hart, K. 1973. 'Informal income opportunities and urban employment in Ghana', Fournal of Modern African Studies II, I: 6I-89.

Holland, J. \& J. Blackburn. 1998. Whose Voice? Participatory research and policy change. London: Intermediate Technology Publications.

ILO. 1972. Employment, Incomes and Equality: a strategy for increasing productive employment in Kenya. Geneva: ILO.

InterAcademy Council (IAC). 2004. Realising the Promise and Potential of African Agriculture: science and technology strategies for improving agricultural productivity and food security in Africa. Amsterdam: IAC.

IUCN. 2004. 'Allanblackia seeds help Ghanaian communities improve livelihoods', News Release, I3 May, IUCN.

Jones, W. O. 1959. Manioc in Africa. Stanford, CA: Stanford University Press.

Kabira, J. 2002. 'Linking ware potato growers with processors of french-fries in Nakuru District, Kenya', paper prepared for Kenya Agricultural Research Institute (KARI).

Kim, W. C. \& R. A. Mauborgne. 200I. 'Creating new market space', in Harvard Business Review on Innovation. Boston, MA: Harvard Business School Press, I-30.

Koruna, S. 2004. 'Leveraging knowledge assets combinative capabilities: theory and practice', $R E D$ Management 34, 5: 505-16.

Kuyek, D. 2002. 'Intellectual property rights in African agriculture: implications for small farmers', GRAIN Briefing, Madrid, available at: http://www.grain.org/briefings/?id= 3

Lofchie, M. 1989. The Policy Factor in Agricultural Performance in Kenya and Tanzania. Boulder, CO: Lynne Rienner.

Luthje, C. \& C. Herstatt. 2004. 'The lead user method: an outline of empirical findings and issues for future research', RED Management $34,5: 554^{-68 .}$ 
Lynam, J. \& H. Elliot. 2004. Organising Agricultural Research: fitting institutional structure to the research agenda. East Lansing, MI: Michigan State University Press.

Lynam, J., C. G. Ndiritu \& A. Mbabu. 2004. Transformation of Agricultural Research Systems in Africa: lessons from Kenya. East Lansing, MI: Michigan State University Press.

Mackenzie, F. 1998. Land Ecology and Resistance in Kenya. Edinburgh: Edinburgh University Press.

Martin, J. I995. 'Ignore your customer', Fortune, May: I23-6.

Martin, M. J. C. \& J. K. Hall. 2005. 'Disruptive technologies, stakeholders and the innovation valueadded chain: a framework for evaluating radical technology development, REDD Management 35, 3: $273-84$.

Mayoux, L. 2003. 'Trickle-down, trickle-up or puddle? Participatory value chains analysis for pro-poor enterprise development', Wise Development, available at: http://www.enterpriseimpact.org.uk/word-files/ValueChainsAnalysis.doc

McGrath, M. E. 1995. Product Strategy for High Technology Companies: how to achieve growth, competitive advantage, and increased profits. New York: McGraw-Hill.

Minae, S. 2005. 'Implications of globalisation on commodity markets under contract farming', paper presented at the NEPAD Contract Farming in Africa Conference, Entebbe, Uganda, 22-26 November.

Mkamilo, G. S. 2005. 'Current status of cassava improvement programme in Tanzania', paper presented at a workshop on molecular marker-assisted and participatory plant breeding, Kunduchi Beach Hotel, Dar-es-Salaam, I2-I6 September.

Morgan, K. I997. 'The learning region: institutions, innovation and regional renewal', Regional Studies 3I, 5: 49I-503.

Moser, C. I978. 'Informal sector or petty commodity production: dualism or independence in urban development', World Development 6: I04I-64.

NEPAD. 2002. 'Comprehensive African agriculture development programme', available at: http:// www.sarpn.org.za/documents/doooro39/index.php

Nishiguchi, T. I994. Strategic Industrial Sourcing: the Fapanese advantage. Oxford University Press.

Nweke, N. 2004. 'New challenges in the cassava transformation in Nigeria and Ghana', discussion paper series No. iı8, Environmental and Production Technology Division, International Food Policy Research Institute, Washington, DC.

Ochieng, C. 2005. 'The political economy of contract farming in Kenya, I963-2002', D.Phil. Thesis, Oxford University.

Penning, C. I998. Bike History. Bielefeld: Delius \& Klasing.

Penrose, E. G. I959. The Theory of the Growth of the Firm. New York: Wiley.

Popper, K. I959. Conjectures and Refutations. New York: Harper and Row.

Portes, A., M. Castells \& L. Benton, eds. I989. The Informal Economy: studies in advanced and less developed countries. Baltimore, MD: The Johns Hopkins University Press.

Prahalad, C. K. 2005. The Fortune at the Bottom of the Pyramid. Philadelphia, PA: Wharton School Publishing.

Programme on Regional Potato and Sweet Potato Improvement in Eastern and Central Africa (PRAPACE). 2003. 'Five-Year Priority Setting, 2003-2008', Kampala: PRAPACE.

Reij, C. \& N. Waters-Bayer. 200I. Farmer Innovation in Africa. London: Earthscan.

Rosegrant M. W., G. J. Scott \& C. Ringler. 2000. 'Roots and tubers for the 2ist century: trends, projection and policy options', discussion paper series No. 3I, Food, Agriculture, and the Environment Division, IFPRI, Washington, DC.

Rosenberg, N. I976. Perspectives on Technology. Cambridge University Press.

Rothwell, R. I994. 'Towards fifth-generation process innovation', International Marketing Review, I I, I: $7^{-} 3^{\mathrm{I}}$.

Schultz, T. W. I964. Transforming Traditional Agriculture. New Haven, GT: Yale University Press.

Schultz, T. W. I979. 'The economics of being poor', Nobel Prize Lecture, 8 December, available at: http://nobelprize.org/nobel_prizes/economics/laureates/I979/schultz-lecture.html

Schumpeter, J. A. I934. The Theory of Economic Development. Cambridge MA: Harvard University Press.

Scoones, I., S. Devereux \& L. Haddad. 2005. 'New directions for African agriculture', IDS Bulletin 36,2 .

Sen, A. K. I98I. Poverty and Famines: an essay on entitlements and deprivation. Oxford: Clarendon Press.

Sen, A. K. I985. Commodities and Capabilities. Amsterdam: North-Holland.

Sen, A. K. I999. Development as Freedom. Oxford University Press. 
Shah, S. 2000. 'Sources and patterns of innovation in a consumer products field: innovations in sporting equipment', working paper No. 4I05. Sloan School of Management, Massachusetts Institute of Technology, Cambridge, MA.

Shaw, B. I985. 'The role of the interaction between the user and the manufacturer in medical equipment innovation', RED Management $\mathrm{I} 5,4: 283-92$.

Sonnack, M., S. Thomke \& E. von Hippel. 2001. 'Creating breakthroughs at ${ }_{3} \mathrm{M}$ ', Harvard Business Review 77, 5: 47-57.

South African Medical Research Council (SAMRC). 2004. 'Not an ordinary Sweet Potato', press release, http://www.mrc.ac.za/mrcnews/sep2004/sweetpotato.htm

Sperling, L., J. A. Ashby, M. E. Smith, E. Weltzien \& S. McGuire. 200I. 'A framework for analysing participatory plant breeding approaches and results', Euphytica, I22: 439-50.

Taylor, S., T. Phillips, L. Sanni \& M. Akoroda. 2004. 'A cassava industrial revolution in Nigeria: the potential for a new industrial crop', Rome: IFAD \& FAO.

Teece, D. 1986. 'Profiting from technological innovation', Research Policy I5: 285-305.

Terziovski, M., D. Samson \& L. Glassop. 200 . 'Creating core competence through the management of organizational innovation', Foundation for Sustainable Economic Development, available at: http://www.fsed.org/researchprojects/projecti.html.

Thurston, A. 1987. 'Smallholder agriculture in Kenya: the official mind and the Swynnerton Plan', Cambridge University: African Studies Centre.

Tripp, R., M. Wijeratne \& H. Piyadasa. 2005. 'What should we expect from farmer field schools? A Sri Lanka case study', World Development 33, 10: 1705-20.

Tushman, M. \& P. Anderson. I986. 'Technological discontinuities and organisational environments', Administrative Science Quarterly, 31 : 439-65.

UNDP. 2005. 'Growing sustainable business for poverty reduction Tanzania', Newsletter. September.

UNECA. 2005. 'Emerging issues in science and technology for Africa's development', Fourth Meeting of the Committee on Sustainable Development, Addis Ababa, October.

Unilever 2006. 'Africa: promoting biodiversity and alleviating poverty in Ghana \& Tanzania', http:// www.unilever.com/ourvalues/environmentandsociety/casestudies/economicDev/allanblackia_ seeds.asp.

USAID. 2006. http://www.usaidkenya.org/ke.agbuen/activities/women_dvpt.html. accessed I9July.

Usher, A. P. I954. A History of Mechanical Invention. Cambridge, MA: Harvard University Press.

Utterback, J. M., T. J. Allen, J. H. Hollomon \& M. A. Sirbu. 1976. 'The process of innovation in five industries in Europe and Japan', IEEE Transactions on Engineering Management, EM-23, I: 3-9.

Vernooy, R. 2003. Seeds that Give: a vision for the future. Ottawa: IDRG. available at: http://www.idrc.ca/ en/ev-30294-20I-I-DO_TOPIC.html

von Hippel, E. I976. 'The dominant role of users in the scientific instrument innovation process', Research Policy 5: 212-39.

von Hippel, E. I986. 'Lead users: a source of novel product concepts', Management Science 32, 7 : $79 \mathrm{I}-805$.

von Hippel, E. I987. 'Cooperation between rivals: information know-how trading', Research Policy i6, 6: $29 \mathrm{I}-302$.

von Hippel, E. I998. 'Economics of product development by users: the impact of 'sticky' local information', Management Science 44, 5: 629-44.

Voss, C. A. I985. 'The role of users in the development of applications software', Fournal of Product Innovation Management 2, I: II $3-2$ I.

Watts, M. J. I983. Silent Violence: food, famine and peasantry in Northern Nigeria. Berkeley, CA: University of California Press.

Watts, M. J. 2000. 'Struggles over geography: violence, freedom and development at the millennium', Hettner Lectures No. 3, University of Heidelberg: Department of Geography.

Watts, M. J. \& H. Bohle. I993. 'The space of vulnerability: the causal structure of hunger and famine', Progress in Human Geography I7, I: 43-67.

Wiggins, S. 2005. 'Success stories from African agriculture: what are the key elements of success?' IDS Bulletin $36,2$.

World Bank. 2002. World development indicators. Oxford University Press. 